\title{
UNDERSTORY CONDITION IN AN OAK FOREST AFTER 4 DECADES FOR OAK DECLINE IN HUNGARY
}

\author{
Tamás Misik* \& Imre Kárász \\ Eszterházy Károly University, Institute of Geography and Environmental Sciences, \\ Department of Environmental Sciences and Landscape Ecology, H-3300 Eger, \\ Leányka str. 6, Hungary; *E-mail: misik.tamas@uni-eszterhazy.hu
}

\begin{abstract}
At the study area serious oak decline was detected from 1979-80 in a mixed oak forest, an area covered by a sessile oak-Turkey oak forest (Quercetum petraeae-cerridis). The shrub community was divided into low (lower than $1.0 \mathrm{~m}$ in height) and high shrub layer $(\geq 1.0 \mathrm{~m})$. The goals of this study were to determine the conditions of shrub layer and analyse the possible changes in the shrub layer after 4 decades of the serious oak decline. In 2017, 17 shrub species were continuously observed in the understory. The density of shrub layer was 25,103 specimens ha $^{-1}$. The significant part of shrubs lived $(91.6 \%)$ in the low shrub layer, with only a small part of them (8.4\%) forming the high shrub layer. The most common species of the shrub community was Euonymus verrucosus with 1989 shoots in the monitoring plot. The mean height and mean diameter of the high shrub species changed between $1.29-8.74 \mathrm{~m}$ and between $0.81-9.61 \mathrm{~cm}$. The mean cover of the high shrub species changed between $0.56 \mathrm{~m}^{2}$ and $12.67 \mathrm{~m}^{2}$. Our results suggest that three woody species, Acer campestre, Acer tataricum and Cornus mas responded successfully to the oak decline.
\end{abstract}

Keywords: shrub layer, Síkfőkút Project, field maple, mean size, foliage cover

\section{INTRODUCTION}

Oak decline has been described as a widespread and complex phenomenon in many countries (Tomiczek 1993, Sonesson and Drobyshev 2010). An increase in the death of oak species has been observed in many regions of Hungary since 1978 (Igmándy et al. 1987). In the Síkfőkút research stand (Quercetum petraeae-cerridis Soó 1963) species composition of the canopy was stable until 1979 and the healthy Quercus petraea Matt. L. (sessile oak) and Quercus cerris L. (Turkey oak) also remained constant. Serious oak decline 
was first reported in $1979-80$ and by $2017,62.9 \%$ of the oaks had died.

Relatively few studies deal with shrub communities and shrub layer dynamics after oak death and the relationship between the trees and shrubs (Légaré et al. 2002). Understory and overstory relationships are complex and mutual but are dominated by the canopy structure and condition (Burrascano et al. 2011, Burton et al. 2011, Cutini et al. 2015). Shrub layers of forest ecosystems change dynamically and respond sensitively to the environmental changes (Chipman and Johnson 2002, Rees and Juday 2002). They are strongly related to the composition and structure of the overstory (Klinka et al. 1996, Palik and Engstrom 1999). Shrub species play a major role in the cycles of some essential nutrients, including the dynamics of nitrogen, potassium and carbon (Gilliam 2007). The shrub layers are directly contributes to forest biodiversity (Kerns and Ohmann 2004, Aubin et al. 2009), including compositional and structural diversity, enhancing the aesthetics of forest ecosystems and helping to protect watersheds from erosion (Alaback and Herman 1988, Halpern and Spies 1995, Muir et al. 2002). Shrubs provide food and habitat, among others, for songbirds, forest ungulates and arthropoda (González-Hernández et al. 1998, Yanai et al. 1998), can mitigate forest decline and influence forest regeneration through affecting light availability (Kunstler et al. 2006).

Misik et al. (2013) described the possible responses of parameters of understory shrub layer to the remarkable changes in stand density on the study site. Misik et al. (2014) reported the dynamics behind the increase in the sizes of woody species and the structure of the new subcanopy layer below the canopy.

The aim of the study was to investigate the composition, size condition, foliage cover and diversity of understory shrub layer in the oak forest and analysed how shrub layer changed after four decades of serious oak decline.

\section{MATERIALS AND METHODS}

\section{Study site}

The reserve research site (Síkfőkút Project) was established in 1972 by Jakucs (1985) and is located in the Bükk Mountains $\left(47^{\circ} 552 \mathrm{~N}, 20^{\circ} 462 \mathrm{E}\right)$ in the north-eastern part of Hungary at an 
altitude of 320-340 m a.s.l. and $6 \mathrm{~km}$ from the city of Eger (Figure $1 A$ ). Mean annual temperature is $9.9^{\circ} \mathrm{C}$ and mean annual precipitation ranges typically from 500 to $600 \mathrm{~mm}$. Descriptions of the geographic, climatic, and soil conditions, and vegetation of the forest were reported in detail by Jakucs $(1985,1988)$, Tóth et al. (2013) and Fekete et al. (2014). The Quercetum petraeae-cerridis community with a dominant canopy of $Q$. petraea and $Q$. cerris deciduous tree species structure is presented in the works of Mázsa et al. (2005), Kotroczó et al. (2007) and Fekete et al. (2017); the long-term dynamics of understory shrub layer and oak seedling dynamics are described among others in works of Misik and Kárász (2010) and Misik et al. $(2013,2017)$. The plots under study were made up of evenly aged temperate, mixed species deciduous forest that was at least 110 years old and had not been harvested for more than 55 years.

\section{Sampling and data analysis}

The structural condition of the shrub layer was monitored on an "A" plot at the research site, $48 \mathrm{~m} \times 48 \mathrm{~m}$ in size; the plot was divided into 144 permanent subplots of $4 \mathrm{~m} \times 4 \mathrm{~m}$ (Figure $1 B$ ).

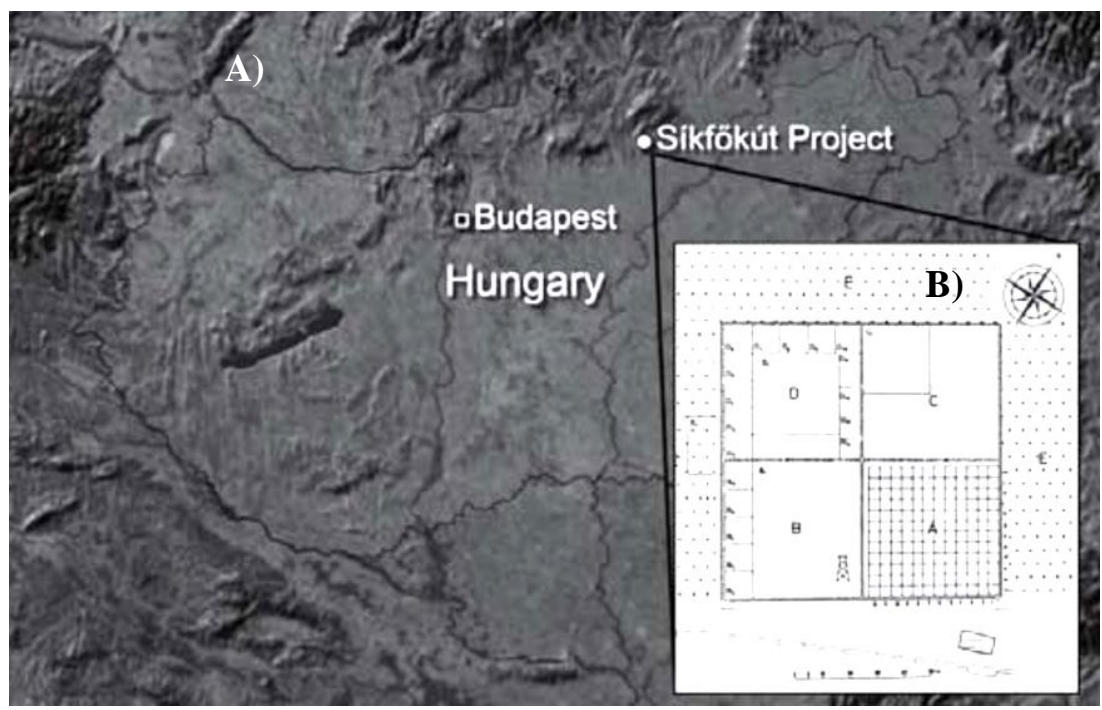

Figure 1.A. Location of the study area in Hungary. B. Study site location with plots. 
The subplots were established in 1972; the understory data collected at subplots measured during the 2017 field season on site. Woody shoots of the understory were classified as subcanopy trees when between $8.0-13.0 \mathrm{~m}$ in height. The shrub specimens of the vegetation lower than $1.0 \mathrm{~m}$ in height were categorized as low understory; higher specimens between $1.0 \mathrm{~m}$ and $8.0 \mathrm{~m}$ were categorized as high understory. Oak stems $<50.0 \mathrm{~cm}$ and between 50.0 and $100.0 \mathrm{~cm}$ in height were inventoried and categorized as oak seedling and oak saplings. The term "dominant woody" is used to refer to certain species that play a key role in a shrub layer based on the high densities and largest mean sizes. The following measurements were carried out for understory shrub species in each subplot: species composition, frequency (occurrence \% in subplots of the monitoring plot), species density, height and diameter, foliage cover of species and of shrub layer and finally diversity indices. The shrub specimen's density was extrapolated for one hectare. It was recorded the specimen height with a scaled pole and the diameter at a height of $5 \mathrm{~cm}$ above the soil surface with a digital calliper. The size condition of each high shrub specimen was measured; in the low shrub layer, a number of specimens were randomly selected in proportion to the species density to determine the size parameters. Effective foliage, duplexand multiplex (shrub canopy overlapped other shrubs) and finally the simplified cover on the basis of all the shrub specimens foliage of the shrub layer were recorded in the quarter hectare plot. The following diversity indices were used: Shannon-index $(\mathrm{H})$ and Evenness (E).

$\mathrm{H}^{\prime}=-\Sigma\left(\mathrm{p}_{\mathrm{i}} \times \ln \mathrm{p}_{\mathrm{i}}\right)$

$\mathrm{E}=\mathrm{H}^{\prime} / \mathrm{H}_{\max }=\mathrm{H}^{\prime} / \operatorname{lnS}$

where: $p_{i}$ - proportion of specimens found in the $i^{\text {th }}$ species, $S$ total number of species in the shrub layer. Evenness was calculated as the ratio of observed diversity $(\mathrm{H})$ to maximum diversity $\left(\mathrm{H}_{\max }\right)$ (Magurran 1988).

\section{RESULTS}

\section{Composition and density}

Seventeen native woody species were identified across the entire study area in 2017. In the high shrub layer (composed 13 species) was not lived Q. cerris, Quercus pubescens Willd. (downy oak), 
Rhamnus cathartica L. (buckthorn) and Rosa canina L. (dog rose). Three native woody species were detected in the subcanopy layer; Acer campestre L. (field maple), Cornus mas L. (European cornel) and Acer tataricum L. (Tatar maple) (Table 1).

The density of shrub layer per hectare was 25,103 specimens. The most common low shrub species were Euonymus verrucosus Scop. (spindle tree) and $Q$. petraea; the most common high shrubs were A. campestre and E. verrucosus. The significant part of shrubs lived $(91.6 \%)$ in the low shrub layer, with only a small part of them (8.4\%) forming the high shrub layer. The most common species of the shrub community was E. verrucosus with 1989 shoots in the study site; followed them $Q$. petraea and A. campestre (Table 1). Many A. campestre specimens (almost $28 \%$ of these woody species) and some A. tataricum (almost 13\%) and C. mas (8\% of these species) were present as subcanopy species in the sample site below the canopy between $8.0-13.0 \mathrm{~m}$ in 2017 .

Table 1. Species composition and density condition of the understory shrub layer on the Síkfőkút mixed oak forest in 2017.

\begin{tabular}{|c|c|c|c|c|c|c|c|}
\hline \multirow[b]{2}{*}{ species } & \multicolumn{3}{|c|}{ low shrub layer } & \multicolumn{3}{|c|}{ high shrub layer } & \multirow{2}{*}{$\begin{array}{c}\text { total } \\
\text { density } \\
\text { ind. }\end{array}$} \\
\hline & $\begin{array}{l}\text { density } \\
\text { ind. }\end{array}$ & $\begin{array}{l}\text { density } \\
\text { ind. ha-1 }\end{array}$ & $\begin{array}{c}\text { rate } \\
\%\end{array}$ & $\begin{array}{l}\text { density } \\
\text { ind. }\end{array}$ & $\begin{array}{l}\text { density } \\
\text { ind. ha-1 }\end{array}$ & $\begin{array}{c}\text { rate } \\
\%\end{array}$ & \\
\hline A. campestre & 553 & 2400 & 10.44 & 125 & 543 & 25.80 & 678 \\
\hline A. tataricum & 59 & 256 & 1.11 & 20 & 87 & 4.13 & 79 \\
\hline C. mas & 35 & 152 & 0.66 & 86 & 373 & 17.72 & 121 \\
\hline C. sanguinea & 191 & 829 & 3.60 & 46 & 199 & 9.45 & 237 \\
\hline Cr. monogyna & 91 & 395 & 1.72 & 53 & 230 & 10.93 & 144 \\
\hline E. europaeus & 429 & 1862 & 8.10 & 12 & 52 & 2.47 & 441 \\
\hline E. verrucosus & 1866 & 8098 & 35.21 & 123 & 534 & 25.37 & 1989 \\
\hline J. regia & 14 & 61 & 0.26 & 2 & 9 & 0.43 & 16 \\
\hline L. vulgare & 330 & 1432 & 6.23 & 12 & 52 & 2.47 & 342 \\
\hline Lo. xylosteum & 14 & 61 & 0.26 & 2 & 9 & 0.43 & 16 \\
\hline Q. cerris & 146 & 634 & 2.76 & 0 & 0 & 0.00 & 146 \\
\hline Q. petraea & 965 & 4188 & 18.21 & 1 & 4 & 0.19 & 966 \\
\hline Q.pubescens & 480 & 2083 & 9.06 & 0 & 0 & 0.00 & 480 \\
\hline P. avium & 109 & 473 & 2.06 & 2 & 9 & 0.43 & 111 \\
\hline Rh. cathartica & 3 & 13 & $0.05^{-2}$ & 0 & 0 & 0.00 & 3 \\
\hline R. canina & 11 & 48 & 0.21 & 0 & 0 & 0.00 & 11 \\
\hline T. cordata & 3 & 13 & $0.05^{-2}$ & 1 & 4 & 0.19 & 4 \\
\hline total & 5299 & 22998 & 100 & 485 & 2105 & 100 & 5784 \\
\hline
\end{tabular}




\section{Size condition}

The mean height of the shrub species changed between $1.29 \mathrm{~m}$ and $8.74 \mathrm{~m}$ in the high shrub layer [except of the characteristically tree size Prunus avium L. (wild cherry) and Tilia cordata Mill. (smallleaved lime) species]. It was measured 5.26-8.74 m mean height by the dominant woody species of the shrub community. It was recorded between $0.81 \mathrm{~cm}$ and $9.61 \mathrm{~cm}$ mean diameter values of the high shrub species in 2017. The biggest species was the $A$. campestre with $8.74 \mathrm{~m}$ mean height and $9.61 \mathrm{~cm}$ mean diameter.

Table 2. Height and diameter condition (means \pm standard deviation) of the understory shrub layer on the Síkfókút mixed oak forest in 2017.

\begin{tabular}{lccccc}
\hline \multicolumn{1}{c}{ species } & \multicolumn{2}{c}{ low shrub layer } & \multicolumn{2}{c}{ high shrub layer } \\
\cline { 2 - 6 } & $\begin{array}{c}\text { mean } \\
\text { height } \\
\text { (cm } \pm \text { S.D.) }\end{array}$ & $\begin{array}{c}\text { mean } \\
\text { diameter } \\
\text { (mm } \pm \text { S.D.) }\end{array}$ & $\begin{array}{c}\text { measured } \\
\text { shoots } \\
\text { number }\end{array}$ & $\begin{array}{c}\text { mean } \\
\text { height } \\
\text { (m } \pm \text { S.D.) }\end{array}$ & $\begin{array}{c}\text { mean } \\
\text { diameter } \\
\text { (cm } \pm \text { S.D.) }\end{array}$ \\
\hline A. campestre & $16.67 \pm 8.92$ & $3.02 \pm 2.03$ & 76 & $8.74 \pm 5.86$ & $9.61 \pm 5.42$ \\
A. tataricum & $24.30 \pm 17.28$ & $3.85 \pm 2.33$ & 18 & $5.31 \pm 1.88$ & $6.08 \pm 3.00$ \\
C. mas & $39.93 \pm 26.86$ & $4.20 \pm 2.07$ & 19 & $5.26 \pm 1.99$ & $6.95 \pm 2.91$ \\
C. sanguinea & $39.78 \pm 22.55$ & $4.25 \pm 1.75$ & 27 & $1.81 \pm 0.80$ & $1.37 \pm 0.94$ \\
Cr. monogyna & $36.98 \pm 22.88$ & $6.15 \pm 3.20$ & 24 & $2.62 \pm 1.43$ & $3.11 \pm 1.60$ \\
E. europaeus & $18.53 \pm 12.99$ & $3.01 \pm 1.55$ & 55 & $3.43 \pm 0.80$ & $3.88 \pm 1.71$ \\
E. verrucosus & $29.22 \pm 17.99$ & $4.17 \pm 2.18$ & 202 & $1.84 \pm 0.81$ & $2.12 \pm 1.63$ \\
J. regia & $33.74 \pm 11.51$ & $4.15 \pm 1.24$ & 11 & $1.30 \pm 0.21$ & $1.07 \pm 0.16$ \\
L. vulgare & $28.78 \pm 16.21$ & $3.68 \pm 1.81$ & 75 & $1.29 \pm 0.21$ & $0.81 \pm 0.21$ \\
Lo. xylosteum & $41.15 \pm 28.26$ & $5.10 \pm 3.80$ & 6 & $1.43 \pm 0.27$ & $1.82 \pm 0.42$ \\
Q. cerris & $14.50 \pm 5.81$ & $2.03 \pm 1.22$ & 13 & - & - \\
Q. petraea & $13.69 \pm 6.66$ & $2.03 \pm 1.57$ & 148 & $1.16 \pm 0.00$ & $1.79 \pm 0.00$ \\
Q. pubescens & $15.53 \pm 7.18$ & $2.35 \pm 1.51$ & 35 & - & - \\
P. avium & $21.43 \pm 10.50$ & $3.55 \pm 2.53$ & 41 & $10.08 \pm 12.47$ & $15.08 \pm 18.34$ \\
Rh. cathartica & $12.98 \pm 3.39$ & $2.93 \pm 1.80$ & 3 & - & - \\
R. canina & $12.20 \pm 3.76$ & $1.53 \pm 0.93$ & 5 & - & - \\
T. cordata & $22.02 \pm 4.90$ & $20.58 \pm 10.82$ & 3 & $10.46 \pm 0.00$ & $9.87 \pm 0.00$ \\
\hline
\end{tabular}

The biggest height and diameter values were detected for a single A. campestre with $23.40 \mathrm{~m}$ and for a single $P$. avium with $28.04 \mathrm{~cm}$ under the canopy. The mean height of the other shrubs (except of the tree size P. avium and T. cordata species) was $1.86 \mathrm{~m}$. It was recorded $2.00 \mathrm{~cm}$ mean shoot diameter of these species in the high shrub layer. The mean values changed between 12.20 and $41.15 \mathrm{~cm}$ in height and between 1.53 and $6.15 \mathrm{~mm}$ in diameter (except of some T. cordata) in the low shrub layer (Table 2). The highest species was observed as Lo. xylosteum and the thickest as Cr. monogyna among the low shrubs (Table 2). 
Table 3. Foliage cover condition (means \pm standard deviation) of the understory shrub species on the Síkfőkút mixed oak forest in 2017.

\begin{tabular}{|c|c|c|c|c|}
\hline \multirow[b]{2}{*}{ species } & \multicolumn{2}{|c|}{ low shrub layer } & \multicolumn{2}{|c|}{ high shrub layer } \\
\hline & $\begin{array}{l}\text { mean cover } \\
\left(\mathrm{cm}^{2} \pm \text { S.D.) }\right.\end{array}$ & $\begin{array}{l}\text { measured } \\
\text { shoots } \\
\text { number }\end{array}$ & $\begin{array}{c}\text { mean cover } \\
\left(\mathrm{m}^{2} \pm \text { S.D. }\right)\end{array}$ & $\begin{array}{l}\text { total } \\
\text { cover } \\
\left(\mathrm{m}^{2}\right)\end{array}$ \\
\hline A. campestre & $419.98 \pm 291.06$ & 150 & $12.34 \pm 12.16$ & 1542.09 \\
\hline A. tataricum & $500.13 \pm 418.86$ & 31 & $9.97 \pm 7.08$ & 199.39 \\
\hline C. mas & $1561.17 \pm 1469.36$ & 6 & $12.67 \pm 11.28$ & 1089.64 \\
\hline C. sanguinea & $462.71 \pm 410.46$ & 21 & $0.92 \pm 0.98$ & 42.39 \\
\hline Cr. monogyna & $788.35 \pm 743.71$ & 20 & $2.28 \pm 2.73$ & 121.02 \\
\hline E. europaeus & $681.31 \pm 680.82$ & 70 & $3.93 \pm 2.74$ & 47.16 \\
\hline E. verrucosus & $316.83 \pm 246.02$ & 212 & $1.75 \pm 1.93$ & 215.60 \\
\hline J. regia & $1226.14 \pm 650.22$ & 7 & $0.56 \pm 0.22$ & 1.13 \\
\hline L. vulgare & $679.43 \pm 775.65$ & 45 & $0.74 \pm 0.80$ & 8.86 \\
\hline Lo. xylosteum & $2630.57 \pm 1377.09$ & 7 & $0.90 \pm 0.74$ & 1.80 \\
\hline Q. cerris & $275.65 \pm 400.05$ & 17 & - & - \\
\hline Q. petraea & $271.44 \pm 409.36$ & 124 & $3.08 \pm 0.00$ & 3.08 \\
\hline Q. pubescens & $395.68 \pm 858.85$ & 22 & - & - \\
\hline P. avium & $554.94 \pm 584.76$ & 17 & $18.00 \pm 24.01$ & 34.19 \\
\hline Rh. cathartica & $194.67 \pm 125.12$ & 3 & - & - \\
\hline R. canina & $274.29 \pm 454.98$ & 7 & - & - \\
\hline T. cordata & $53.00 \pm 46.70$ & 3 & $13.27 \pm 0.00$ & 13.27 \\
\hline
\end{tabular}

\section{Foliage cover}

The mean cover of the shrub species changed between $0.56 \mathrm{~m}^{2}$ and $12.67 \mathrm{~m}^{2}$ in the high shrub layer. It was measured 9.97-12.67 $\mathrm{m}^{2}$ mean foliage cover by the dominant woody species of the shrub community. The mean cover of other shrubs in the high shrub layer changed between $0.56-3.93 \mathrm{~m}^{2}$. The highest cover values were detected for a two $P$. avium and single T. cordata tree species with $18.00 \mathrm{~m}^{2}$ and with $13.27 \mathrm{~m}^{2}$ under the investigation. In the low shrub layer the mean foliage cover was detected between 195 and $2631 \mathrm{~cm}^{2}$ (except of the three T. cordata specimens because they have lost of own remarkable foliage) (Table 3). In 2017 was measured a relatively high size of the foliage condition. The effective cover was $91.26 \%$, the duplex- and multiplex cover was $44.77 \%$ and was measured $144.08 \%$ total foliage cover in the high shrub layer (Table 4). 
Table 4. Foliage cover condition (rate in $\%$ and size in square meter) of the understory high shrub layer on the Síkfőkút mixed oak forest in 2017.

\begin{tabular}{cccc}
\hline foliage cover & effective cover & $\begin{array}{c}\text { duplex and } \\
\text { multiplex cover }\end{array}$ & simplificalt cover \\
\hline rate $(\%)$ & 91.26 & 44.77 & 144.08 \\
size $\left(\mathrm{m}^{2}\right)$ & 2102.61 & 1031.54 & 3319.62 \\
\hline
\end{tabular}

\section{Diversity indices}

Shannon-Wiener index varied between 1.87 and 2.07 in the understory shrub layer in 2017. The highest index was recorded in the total shrub layer; followed them tightly the low shrubs. In the low shrub layer was measured only 1.39 Shannon index value without oak seedlings and saplings. Evenness index varied between 0.71 and 0.73 in the understory. It was detected a low difference between the different shrub layers. In the low shrub layer was measured 0.53 Evenness value without oak seedlings and saplings (Table 5).

Table 5. Shannon and Evenness indices of the understory shrub layer on the Síkfőkút mixed oak forest in 2017.

\begin{tabular}{ccccc}
\hline index & $\begin{array}{c}\text { layers } \\
\text { layer }\end{array}$ & $\begin{array}{c}\text { low shrubs } \\
\text { without oaks }\end{array}$ & $\begin{array}{c}\text { high shrub } \\
\text { layer }\end{array}$ & $\begin{array}{c}\text { shrub } \\
\text { community }\end{array}$ \\
\hline Shannon & 2.0118 & 1.3900 & 1.8770 & 2.0719 \\
Evenness & 0.7100 & 0.5267 & 0.7318 & 0.7313 \\
\hline
\end{tabular}

\section{DISCUSSION}

The consequences of tree decline cause notable changes in the light and stand thermal conditions which led to structural changes of the shrub layer (Chapman et al. 2006). Our results suggest and confirm that the decreasing tree density in canopy led to the remarkably structural changes of the shrub community. In the past 4 decades despite the heavy oak decline; there is no new shrub species established in the study site of Síkfőkut. Only one woody species, a single T. cordata shoot was established in the forest as new species. Similarly to our site, in the Vár-hegy forest reserve of Hungary the species composition of understorey (herb and shrub layer) did not change after serious oak decline in the 1970s and 1980s (Horváth 2012). The total density of shrub community decreased considerably, from 97,201 to 25,103 specimen's ha-1 on Síkfókút site (Table 1). Refutation, Chapman et al. (2006) described that in 
the upland oak forest of the USA the total shoot density in the understorey were substantially higher in 2002 than in 1934, increasing from 240 to 688 trees ha-1, while the density of most oak and shortleaf pine species in the canopy decreased appreciably over time.

On site the cover percentage of canopy layer decreased remarkably until 1998 after the large-scale oak decline. Consequently, heterogeneous sizes of canopy gaps were formed in the studied forest. A similar situation could be detected in Vár-hegy forest, where $20-50 \%$ of canopy gaps were formed as the consequences of oak decline in the 1980s (Horváth 2012). The autochthonous species $Q$. petraea and $Q$. cerris formed a nearly monolayer canopy (Čermák et al. 2008), therefore they could not fully compensate the significantly reduced foliage cover of canopy after the tree decline. In our forest stand the late seral species, as $A$. campestre and $A$. tataricum are generally shade tolerant and respond positively to canopy gaps. Our results confirm this thesis, because the mean sizes of these species increased considerably in the last 4 decades. Before the oak decline the largest specimen of the shrub layer was one $A$. campestre shoot with 4.9 m height. In 2017 as the largest shrub specimen was recorded also one $A$. campestre with $23.4 \mathrm{~m}$ height. In addition, the mean height and mean diameter values of the three dominant woody species in 2017 exceeded the biggest sizes before the oak decline (Table 2). The rate of the shrub layer's foliage (effective and duplex and multiplex) cover was $64.4 \%$ and $13.8 \%$ before the oak decline. These values increased to $91.3 \%$ and $44.8 \%$ after 4 decades (Table 4).

Shannon index and Evenness varied between 1.53-2.22 and 0.66-0.77 before the oak decline. These values changed only slightly after 4 decades in the shrub layer of the mixed oak forest. The highest negative difference was detected in the low shrub layer (Table 5). Onaindia et al. (2004) results suggested to use Shannon diversity and Evenness indices to evaluate the effects of disturbances in temperate forest stands. In the study of De Grandpré et al. (2011) the Shannon index increased significantly $(P$ $<0.001$ ) with time since treatment application in Canada; along a canopy gap severity gradient in old-growth and mature forest communities. 


\section{CONCLUSIONS}

Seventeen native woody species were identified across the longterm study area in 2017. The high shrub layer composed only 13 woody species. The density of shrub layer was 25,103 specimens ha $^{-1}$ in 2017. The most common low and high shrub species was $E$. verrucosus and A. campestre. The mean height of the shrub species changed between $1.29 \mathrm{~m}$ and $8.74 \mathrm{~m}$ in the high shrub layer. It was recorded between $0.81 \mathrm{~cm}$ and $9.61 \mathrm{~cm}$ mean diameter values of the high shrubs. The mean values changed between 12.20 and $41.15 \mathrm{~cm}$ in height and between 1.53 and $6.15 \mathrm{~mm}$ in diameter in the low shrub species. The mean cover values changed between $0.56 \mathrm{~m}^{2}$ and $12.67 \mathrm{~m}^{2}$ in the high shrub layer. In the low shrub layer the mean foliage cover was detected between 195 and $2631 \mathrm{~cm}^{2}$. Shannon-Wiener index varied between 1.87 and 2.07 in the understory shrub layer of the forest stand. Evenness index varied between 0.71 and 0.73 in the understory. Our results from 2017 suggest that the shrub layer responded positively to the oak decline; this is especially true to the mean sizes of dominant woody species.

\section{REFERENCES}

AlabACK, P.B. \& HERMAN, F.R. (1988). Long-term response of understory vegetation to stand density in Picea-Tsuga forests. Canadian Journal of Forest Research 18: 1522-1530. https://doi.org/10.1139/x88-233

Aubin, I., Ouellette, M.H., Legendre, P., Messier, C. \& Bouchard, A. (2009). Comparison of two plant functional approaches to evaluate natural restoration along an old-field-deciduous forest chronosequence. Journal of Vegetation Science 20: 185-198. https://doi.org/10.1111/j.1654-1103.2009.05513.x

Burrascano, S., Sabatini, F.M. \& Blasi, C. (2011). Testing indicators of sustainable forest management on understorey composition and diversity in southern Italy through variation partitioning. Plant Ecology 212: 829-841. https://doi.org/10.1007/s11258-010-9866-y

Burton, J.I., Mladenoff, D.J., Clayton, M.K. \& Forrester, J.A. (2011). The roles of environmental filtering and colonization in the fine-scale spatial patterning of ground-layer plant communities in north temperate deciduous forests. Journal of Ecology 99: 764-776. https://doi.org/10.1111/j.1365-2745.2011.01807.x

Čermák, J., Tognetti, R., NAdezhdina, N. \& Raschi, A. (2008). Stand structure and foliage distribution in Quercus pubescens and Quercus cerris forests in Tuscany (central Italy). Forest Ecology and Management 255: 1810-1819 https://doi.org/10.1016/j.foreco.2007.12.003 
Chapman, R.A., Heitzman, E. \& Shelton, M.G. (2006). Long-term changes in forest structure and species composition of an upland oak forest in Arkansas. Forest Ecology and Management 236: 85-92.

https://doi.org/10.1016/j.foreco.2006.08.341

Chipman, S.J. \& Johnson, E.A. (2002). Understory vascular plant species diversity in the mixedwood boreal forest of western Canada. Ecological Applications 12: 588-601. https://doi.org/10.1890/1051-0761(2002)012[0588:UVPSDI]2.0.CO;2

Cutini, A., Chianucci, F., Giannini, T., Manetti, M.C. \& Salvati, L. (2015). Is anticipated seed cutting an effective option to accelerate transition to high forest in European beech (Fagus sylvatica L.) coppice stands? Annals of Forest Sciences 72: 631-640. https://doi.org/10.1007/s13595-015-0476-7

De Grandpré, L., Boucher, D., Bergeron, Y. \& GaGnon, D. (2011). Effects of small canopy gaps on boreal mixedwood understory vegetation dynamics. Community Ecology 12: 67-77. https://doi.org/10.1556/ComEc.12.2011.1.9

Fekete, I., Kotroczó, Zs., Varga, Cs, Nagy, P.T., Varbiro, G., Bowden, R.D., Tóth, J.A., \& LAJTHA, K. (2014). Alterations in forest detritus inputs influence soil carbon concentration and soil respiration in a Central-European deciduous forest. Soil Biology \& Biochemistry 74: 106-114. https://doi.org/10.1016/j.soilbio.2014.03.006

Fekete, I., Lajtha, K., Kotroczó, Zs., Varbiro, G., Varga, Cs, Tóth, J.A., Demeter, I., VEPERDI, G. \& BERKI, I. (2017). Long term effects of climate change on carbon storage and tree species composition in a dry deciduous forest. Global Change Biology 23: 3154-3168. https://doi.org/10.1111/gcb.13669

GILLIAM, F.S. (2007). The ecological significance of the herbaceous layer in temperate forest ecosystems. BioScience 57: 845-858. https://doi.org/10.1641/B571007

GonzÁlEz-HernándeZ, M.P., Silva-PAndo, F.J. \& CASAl JimÉnez, M. (1998). Production patterns of understory layers in several Galician (NW Spain) woodlands: Seasonality, net productivity and renewal rates. Forest Ecology and Management 109: 251-259. https://doi.org/10.1016/S0378-1127(98)00253-9

HALPERN, C.B. \& SPIES, T.A. (1995). Plant species diversity in natural and managed forests of the Pacific Northwest. Ecological Applications 5: 913-934. http://dx.doi.org/10.2307/2269343

Horváth, F. (2012). Módszertani fejlesztések az erdőrezervátumok hosszú távú faállomány-szerkezeti kutatásához. [Methodological developments to the long term research of stand structure of forest reserves.] [Ph.D. Thesis.] Sopron, University of West Hungary, Sopron, $80 \mathrm{pp}$.

IgMÁNDY, Z., BÉKY, A., PAGONY, H., SZONTAGH, P. \& VARGA, F. (1987). The state of decay of sessile oak in Hungary in 1985. Az Erdő 35: 255-259.

JaKuCS, P. (ed.) (1985). Ecology of an oak forest in Hungary. Results of „Síkfókút Project" I. Akadémia Kiadó, Budapest, 546 pp.

JAKUCS, P. (1988). Ecological approach to forest decline in Hungary. Ambio 17: 267274.

KeRnS, B.K. \& OHMANN, J.L. (2004). Evaluation and prediction of shrub cover in coastal Oregon forests (USA). Ecological Indicators 4: 83-98. https://doi.org/10.1016/j.ecolind.2003.12.002 
Klinka, K., Chen, H.Y.H., Wang, Q.L. \& De Montigny, L. (1996). Forest canopies and their influence on understory vegetation in early-seral stands on west Vancouver Island. Northwest Science 70: 193-200.

Kotroczó, Zs., Krakomperger, Zs., Koncz, G., PAPP, M., Bowden, R.D. \& Tóth, J.A. (2007). Egy cseres-tölgyes erdő fafaj-összetételének és struktúrájának hosszú távú változása (Síkfőkút Project). Természetvédelmi Közlemények 13: 93-100.

Kunstler, G., Curt, T., Bouchaud, M. \& LePart, J. (2006). Indirect facilitation and competition in tree species colonization of sub-Mediterranean grasslands. Journal of Vegetation Science 17: 379-388. https://doi.org/10.1111/j.1654-1103.2006.tb02458.x

LÉGARÉ, S., BERGERON, Y. \& PARÉ, D. (2002). Influence of forest composition on understory cover of boreal mixedwood forests of western Quebec. Silva Fennica 36: 353-366.

Magurran, A.E. (1988). Ecological Diversity and its Measurement. Princeton University Press, Princeton, NJ. 179 pp.

Mázsa, K., Kotroczó, Zs., Aszalós, R., Bowden, R.D., Bölöni, J., Horváth, F., Kovács, G., KARKOMPERGER, Zs., PAPP, M. \& TóTH, J.A. (2005). Forest dynamical processes: decline and regeneration in sessile oak forests in the Bükk Mts. (Hungary). In: Abstracts and Participants: Bridging the Gap - Policies and Science as Tools in Implementing Sustainable Forest Management, International Conference, Alnarp, South Sweden, p. 63.

MISIK, T. \& KÁRÁSZ, I. (2010). Data to the changes in the structure of shrub layer in a Hungarian oak-forest ecosystem. Acta Universitatis Sapientiae Agriculture and Environment 2: 45-57.

MisiK, T., VARGA, K., Veres, Zs., KÁRÁsZ, I. \& TóthmÉRÉSZ, B. (2013). Long-term response of understorey cover, basal area and diversity to stand density in a mixed oak forest on the Síkfõkút plot in Hungary. Journal of Forest Science 59: 319-327.

MisiK, T., KÁRÁSZ, I. \& TóTHMÉRÉSZ, B. (2014). Understory development in an oak forest in Northern-Hungary: the subcanopy layer. Acta Silvatica et Lignaria Hungarica 10: 9-21. https://doi.org/10.2478/aslh-2014-0001

Misik, T., Kotroczó, Zs., KÁRÁsz, I. \& TóTHMÉRÉSZ, B. (2017). Long-term oak seedling Dynamics and regeneration ability in a deciduous forest in Hungary. Baltic Forestry 23: 595-602.

Muir P.S., Mattingly, R.L., TAPPeiner, J.C., Bailey, J.D., Elliott, W.E., Hager, J.C., Miller, J.C., Peterson, E.B. \& StARKeY, E.E. (2002). Managing for biodiversity in young Douglas-fir forests of Western Oregon. Biological Science Report. US Geological Survey, Forest and Rangeland Ecosystem Science Center, Corvallis, OR. p. 76.

Onaindia, M., Dominguez, I., Albizu, I., Garbisu, C. \& AmezAGa I. (2004). Vegetation diversity and vertical structure as indicators of forest disturbance. Forest Ecology and Management 195: 341-354. https://doi.org/10.1016/j.foreco.2004.02.059

Palik, B. \& Engstrom, R.T. (1999). Species composition. In: Hunter, M.J. (ed.) Maintaining Biodiversity in Forest Ecosystems. Cambridge University Press, Cambridge, UK, pp. 65-94.

REES, D.C. \& JuDAY, G.P. (2002). Plant species diversity on logged versus burned sites in central Alaska. Forest Ecology and Management 155: 291-302. https://doi.org/10.1016/S0378-1127(01)00566-7 
Sonesson, K. \& Drobyshev, I. (2010). Recent advances on oak decline in southern Sweden. Ecological Bulletins 53: 197-207.

Toмiczeк, C. (1993). Oak decline in Austria and Europe. Journal of Arboriculture 19: 71-73.

Tóth, J.A., Nagy, P.T., Krakomperger, Z., Veres, Z., Kotroczó, Z., Kincses, S., Fekete, I., PAPP, M., MÉsZÁros, I. \& VIKTOR, O. (2013). The effects of climate change on element content and soil pH (Síkfókút DIRT Project, Northern Hungary). In: KozaK, J., Katarzyna, O., Bytnerowicz, A. \& WyżGa, B. (eds.) The Carpathians: Integrating Nature and Society Towards Sustainability, Environmental Science and Engineering. Springer-Verlag, Berlin Heidelberg, pp. 77-88.

YANAI, RD., TWERY, M.J. \& STOUT, S.L. (1998). Woody understory response to changes in overstory density: thinning in Allegheny hardwoods. Forest Ecology and Management 102: 45-60.

https://doi.org/10.1016/S0378-1127(97)00117-5

(submitted: 22.09.2019, accepted: 01.12.2019) 